\title{
Effects of Milbemycin D on Microfilarial Number and Reproduction of Dirofilaria immitis in Dogs
}

\author{
Yoshihide SASAKI and Hitoshi KITAGAWA \\ Laboratory of Internal Medicine, Division of Veterinary Medicine, Faculty of Agriculture, Gifu University, 1-1 Yanagido, Gifu 501-11, \\ Japan
}

(Received 11 August 1992/Accepted 25 May 1993)

\begin{abstract}
A single dose $(1 \mathrm{mg} / \mathrm{kg})$ of milbemycin D was administered orally to 24 dogs with microfilaremia of Dirofilaria immitis, and the number of circulating microfilariae was counted weekly. The number was decreased by 3 to $8 \%$ of the pretreatment levels 1 week after the drug administration. The number remained relatively stable for the first 8 weeks and was gradually increased thereafter without returning to the pretreatment levels by 20 weeks. Three or 4 dogs each were euthanatized on day 1 , and 1, 4, 8, 12, 16 and 20 weeks after the drug administration to examine the effects of the drug on intrauterine microfilariae and embryos of the worms. Although no intrauterine microfilariae were destroyed directly by the drug, degeneration and collapse of morular embryos and decrease in the number of intrauterine microfilariae were observed 12 after weeks the drug administration. These findings became more remarkable with time, and no intrauterine microfilariae developed in any worms by 20 weeks. The electron-microscopic findings revealed that the nucleoli of oocytes had a high density in the worms of 1,4 and 8 week groups. Unequal size of cleavage cells and decrease of polysome number were noticed in the early-stage embryos after 8 weeks. It was assumed that the drug might have some effect on the chromosomes or genes in the germinal stem-cell of the heartworm and interfere with protein syntheses, resulting in inhibition of embryonic development. Twelve dogs were given milbemycin $\mathrm{D}(1 \mathrm{mg} / \mathrm{kg})$ a total of 4 or 6 times monthly according to a prophylactic program. Circulating microfilariae disappeared after 1 to 5 treatments, and none of them were confirmed at the beginning of the next mosquito season. Milbemycin D was considered to inhibit the development of heartworm embryos and to induce occult heartworm infection.-KEY worDs: canine, heartworm, microfilaria, milbemycin $\mathrm{D}$, occult infection.
\end{abstract}

J. Vet. Med. Sci. 55(5): 763-769, 1993

It has been reported that milbemycin $\mathrm{D}$ has an antiparasitic effect on microfilariae and larvae of Dirofilaria immitis (heartworm) [10, 14]. Tagawa et al. [14] reported that heartworm infection was completetely prevented by the oral treatment with $1 \mathrm{mg} / \mathrm{kg}$ of milbemycin $\mathrm{D}$ at two-month intervals after the inoculation of infective larvae. Monthly administration of the drug at a dose of 1 $\mathrm{mg} / \mathrm{kg}$ throughout the mosquito season has been used as a prophylactic program in Japan since 1987.

The number of circulating microfilaria was markedly decreased within $24 \mathrm{hrs}$ after the administration of $1 \mathrm{mg} / \mathrm{kg}$ of milbemycin D [11, 13]. However, long-term monitoring of the microfilaria number followed by the drug administration has not been reported. The number of circulating microfilaria was considered to depend on the number of intravascular microfilariae killed and the number reproduced from the adult worms after microfilaricide treatment [1]. It has been reported that the germinal cells, embryos and microfilariae in the ovary or the uteri of filarioidea were injured after the treatment with some microfilaricides $[1,2,4,15,17]$. However, no studies have ever tried to clarify the effect of milbemycin $D$ on the reproduction of heartworms.

This paper describes the change in the number of circulating microfilaria and the consecutive morphological changes in the intrauterine microfilariae and embryos of heartworms after milbemycin $\mathrm{D}$ administration in dogs.

\section{MATERIALS AND METHODS}

1. Changes in the number of circulating microfilaria Experimental dogs: Forty-two dogs, 2 to 7 years old, weighing 7 to $16 \mathrm{~kg}$, naturally infected with heartworms and microfilaremia, were used. These dogs were reared in a conventional doghouse and fed commercial dogfood throughout the experimental period.

Single-dose experiment: Twenty-four of 30 dogs were given orally a single dose of $1 \mathrm{mg} / \mathrm{kg}$ of milbemycin $\mathrm{D}$ (Sankyo Co., Ltd., Tokyo), then the number of circulating microfilariae was counted on day 1 , and at weekly intervals for 20 weeks. Three or four dogs were euthanatized to observe morphological changes in reproductive organs in female heartworms on day 1 , and 1, 4, 8, 12, 16 and 20 weeks after the administration (1-day, and 1-, 4-, 8-, 12-, 16- and 20-week groups, respectively). Two dogs (adult-worm eliminated group) were treated intravascularly with $2.2 \mathrm{mg} / \mathrm{kg}$ thiacetarsamide (Filaramide, Fromm Laboratories, Inc., Grafton, Wisconsin) twice daily for 3 days to eliminate adult heartworms, then given orally milbemycin $\mathrm{D}(1 \mathrm{mg} / \mathrm{kg}) 7$ weeks after the thiacetarsamide treatment. Microfilariae were counted weekly up to 5 weeks after the administration. Four dogs (control group) were not treated with any drug. Blood samples were collected between 8 and 10 A.M. to exclude daily periodic effects. Microfilariae were counted by the same method as in the previous report [13].

Multiple-dose experiment: Eight of 12 dogs were given 
milbemycin $\mathrm{D}(1 \mathrm{mg} / \mathrm{kg})$ a total of 6 times at monthly intervals from June to November, and the other 4 dogs a total of 4 times from August to November. The number of circulating microfilariae was counted before the drug administration and at monthly intervals till 1 month after the final treatment. The number of microfilariae was also counted 12 and 10 months after the first treatment (7 months after the final treatment in June of the following year) in 10 dogs, and 20 months after the first treatment (14 months after the final treatment) in one dog.

2. Effect on microfilaria reproduction

Three to 10 worms were collected from the dogs of each group in the single-dose experiment. Four worms were collected from a dog euthanatized at 20 months after the 1 st treatment in the multiple-dose experiment. Microfilariae collected from the uteri of heartworms in dogs of the 1-day, and 1- and 4-week groups were put in a small amount of saline on a warmed glass slide. Their motion was observed under the light microscopy to determine whether microfilariae were dead or alive. For histological observation of the worms, the whole worm was fixed with $70 \%$ ethanol after washing the body surface with saline, dehydrated in a series of ethanol, embedded in paraffin, and cut into pieces of about $1 \mathrm{~cm}$ length from head to tail. Each piece was sectioned and stained with hematoxylin and eosin.

For electron-microscopic observation, the whole worm was fixed in cold $2 \%$ glutaraldehyde $-2 \%$ paraformaldehyde solution after washing the body surface with saline, and cut into pieces of about $5 \mathrm{~mm}$ in length. Each piece was fixed further with $2 \%$ osmium tetroxide, dehydrated with an ethanol series, and embedded with epoxy resin mixture. Ultrathin sections were made by the routine method and stained with uranyl acetate and lead citrate.

RESULTS

1. Changes in the number of circulating microfilaria

Single-dose experiment: Changes in the mean number of microfilaria in the single-dose experiment are shown in Table 1 and Fig. 1. In the adult-worm eliminated group, a small number of microfilariae were detected from 1 day to 5 weeks after the drug administration.

In the other groups treated with the drug, the mean numbers of microfilaria were decreased by 3 to $8 \%$ of the pretreatment levels 1 week after the treatment, and remained relatively stable until 8 weeks after the treatment except the 12-week group. The numbers began to increase after 9 weeks, but did not reach the pretreatment levels. In 1 of 3 dogs in the 12-week group, the number was decreased by $7 \%$ of the pretreatment level 3 weeks after the administration, and began to increase at the 4th week, exceeding the pretreatment level at the 6th week.

Three to 61 (18 in average) female worms were observed in each dog, and none in the adult-worm eliminated group. The number of adult worms did not correlate with that of circulating microfilaria before and after the treatment.

Multiple-dose experiment: Changes in the number of microfilaria in the multiple-dose experiment are shown in Table 2. Circulating microfilariae disappeared after a

Table 1. The mean numbers of circulating microfilariae followed by a single dose $(1 \mathrm{mg} / \mathrm{kg})$ of milbemycin $\mathrm{D}$ in dogs

\begin{tabular}{|c|c|c|c|c|c|c|c|c|c|c|c|c|c|c|c|c|c|c|c|c|c|c|}
\hline \multirow{2}{*}{ Group } & \multicolumn{22}{|c|}{ Day and weeks after milbemycin $\mathrm{D}$ administration } \\
\hline & $0^{a)}$ & $1 d^{\text {b) }}$ & $1 w^{c)}$ & $2 w$ & $3 w$ & $4 w$ & $5 \mathrm{w}$ & $6 w$ & $7 \mathrm{w}$ & $8 w$ & $9 w$ & $10 \mathrm{w}$ & $11 w$ & $12 \mathrm{w}$ & $13 w$ & $14 \mathrm{w}$ & $15 \mathrm{w}$ & $16 w$ & $17 \mathrm{w}$ & $18 \mathrm{w}$ & $19 w$ & $20 \mathrm{w}$ \\
\hline $\begin{array}{l}\text { I day } \\
(n=3)\end{array}$ & $\begin{array}{l}2582^{\mathrm{d})} \\
(100)^{\mathrm{f}}\end{array}$ & $\begin{array}{l}222 \\
(9)\end{array}$ & $\left.\ldots{ }^{e}\right)$ & $\cdots$ & $\ldots$ & $\cdots$ & $\cdots$ & $\cdots$ & $\ldots$ & $\cdots$ & $\cdots$ & $\cdots$ & $\cdots$ & $\cdots$ & $\ldots$ & $\ldots$ & $\ldots$ & ... & $\ldots$ & $\ldots$ & $\ldots$ & $\ldots$ \\
\hline $\begin{array}{l}1 \text { week } \\
(n=4)\end{array}$ & $\begin{array}{c}3963 \\
(100)\end{array}$ & $\begin{array}{l}285 \\
(7)\end{array}$ & $\begin{array}{l}247 \\
(6)\end{array}$ & $\ldots$ & $\cdots$ & $\cdots$ & $\ldots$ & $\cdots$ & $\ldots$ & $\ldots$ & $\ldots$ & $\cdots$ & $\ldots$ & $\ldots$ & $\ldots$ & $\cdots$ & $\ldots$ & $\ldots$ & $\cdots$ & $\ldots$ & $\ldots$ & $\ldots$ \\
\hline $\begin{array}{l}4 \text { week } \\
(n=3)\end{array}$ & $\begin{array}{c}3153 \\
(100)\end{array}$ & $\begin{array}{l}453 \\
(14)\end{array}$ & $\begin{array}{l}251 \\
(8)\end{array}$ & $\begin{array}{l}100 \\
(3)\end{array}$ & $\begin{array}{l}229 \\
(7)\end{array}$ & $\begin{array}{l}285 \\
(9)\end{array}$ & $\ldots$ & $\ldots$ & $\ldots$ & $\ldots$ & $\ldots$ & $\ldots$ & $\ldots$ & $\ldots$ & $\ldots$ & $\ldots$ & $\ldots$ & $\ldots$ & $\ldots$ & $\ldots$ & $\ldots$ & $\ldots$ \\
\hline $\begin{array}{l}8 \text { week } \\
(\mathrm{n}=4)\end{array}$ & $\begin{array}{c}2756 \\
(100)\end{array}$ & $\begin{array}{l}415 \\
(15)\end{array}$ & $\begin{array}{l}155 \\
(6)\end{array}$ & $\begin{array}{l}76 \\
\text { (3) }\end{array}$ & $\begin{array}{l}92 \\
\text { (3) }\end{array}$ & $\begin{array}{l}107 \\
\text { (4) }\end{array}$ & $\begin{array}{l}147 \\
(5)\end{array}$ & $\begin{array}{l}111 \\
(4)\end{array}$ & $\begin{array}{l}95 \\
\text { (3) }\end{array}$ & $\begin{array}{l}167 \\
(6)\end{array}$ & $\ldots$ & $\ldots$ & $\ldots$ & $\ldots$ & $\ldots$ & $\ldots$ & $\ldots$ & $\ldots$ & $\ldots$ & $\ldots$ & $\ldots$ & $\ldots$ \\
\hline $\begin{array}{l}12 \text { week } \\
(n=3)\end{array}$ & $\begin{array}{r}2360 \\
(100)\end{array}$ & $\begin{array}{l}584 \\
(25)\end{array}$ & $\begin{array}{l}132 \\
(6)\end{array}$ & $\begin{array}{l}156 \\
(7)\end{array}$ & $\begin{array}{l}163 \\
\text { (7) }\end{array}$ & $\begin{array}{l}371 \\
(15)\end{array}$ & $\begin{array}{l}350 \\
(15)\end{array}$ & $\begin{array}{l}597 \\
(25)\end{array}$ & $\begin{array}{l}666 \\
(28)\end{array}$ & $\begin{array}{l}830 \\
(35)\end{array}$ & $\begin{array}{l}1422 \\
(60)\end{array}$ & $\begin{array}{l}1989 \\
(84)\end{array}$ & $\begin{array}{l}2263 \\
(96)\end{array}$ & $\begin{array}{l}2637 \\
(112)\end{array}$ & $\ldots$ & $\ldots$ & $\ldots$ & $\ldots$ & $\ldots$ & $\ldots$ & $\ldots$ & $\ldots$ \\
\hline $\begin{array}{l}16 \text { week } \\
(n=3)\end{array}$ & $\begin{array}{l}2146 \\
(100)\end{array}$ & $\begin{array}{l}376 \\
(28)\end{array}$ & $\begin{array}{l}149 \\
(7)\end{array}$ & $\begin{array}{l}120 \\
(6)\end{array}$ & $\begin{array}{l}113 \\
(5)\end{array}$ & $\begin{array}{l}128 \\
(6)\end{array}$ & $\begin{array}{l}101 \\
(5)\end{array}$ & $\begin{array}{l}92 \\
\text { (4) }\end{array}$ & $\begin{array}{l}118 \\
(6)\end{array}$ & $\begin{array}{l}237 \\
(11)\end{array}$ & $\begin{array}{l}378 \\
(18)\end{array}$ & $\begin{array}{l}554 \\
(26)\end{array}$ & $\begin{array}{l}763 \\
(36)\end{array}$ & $\begin{array}{l}765 \\
(36)\end{array}$ & $\begin{array}{l}1281 \\
(60)\end{array}$ & $\begin{array}{l}1577 \\
(73)\end{array}$ & $\begin{array}{l}1653 \\
(77)\end{array}$ & $\begin{array}{l}1536 \\
(72)\end{array}$ & $\ldots$ & $\ldots$ & $\ldots$ & $\ldots$ \\
\hline $\begin{array}{l}20 \text { week } \\
(n=4)\end{array}$ & $\begin{array}{l}3269 \\
(100)\end{array}$ & $\begin{array}{l}239 \\
(7)\end{array}$ & $\begin{array}{l}101 \\
\text { (3) }\end{array}$ & $\begin{array}{l}62 \\
(2)\end{array}$ & $\begin{array}{l}68 \\
(2)\end{array}$ & $\begin{array}{l}61 \\
(2)\end{array}$ & $\begin{array}{l}67 \\
(2)\end{array}$ & $\begin{array}{l}112 \\
\text { (3) }\end{array}$ & $\begin{array}{l}152 \\
(5)\end{array}$ & $\begin{array}{l}145 \\
\text { (4) }\end{array}$ & $\begin{array}{l}405 \\
(12)\end{array}$ & $\begin{array}{l}408 \\
(12)\end{array}$ & $\begin{array}{l}500 \\
(15)\end{array}$ & $\begin{array}{l}772 \\
(24)\end{array}$ & $\begin{array}{l}974 \\
(30)\end{array}$ & $\begin{array}{l}1030 \\
(32)\end{array}$ & $\begin{array}{l}1143 \\
(35)\end{array}$ & $\begin{array}{l}1149 \\
(35)\end{array}$ & $\begin{array}{l}1313 \\
(40)\end{array}$ & $\begin{array}{l}1579 \\
(48)\end{array}$ & $\begin{array}{l}1136 \\
(35)\end{array}$ & $\begin{array}{l}1475 \\
(45)\end{array}$ \\
\hline $\begin{array}{l}\left.A W E^{g}\right) \\
(n=2)\end{array}$ & $\begin{array}{l}2864 \\
(100)\end{array}$ & $\begin{array}{c}7 \\
(0.2)\end{array}$ & $\begin{array}{c}1 \\
(0.04)\end{array}$ & $\begin{array}{c}1 \\
(0.04)\end{array}$ & $\begin{array}{c}7 \\
(0.2)\end{array}$ & $\begin{array}{c}4 \\
(0.1)\end{array}$ & $\begin{array}{c}1 \\
(0.04)\end{array}$ & $\ldots$ & $\ldots$ & $\ldots$ & $\ldots$ & $\ldots$ & $\ldots$ & $\ldots$ & $\ldots$ & $\ldots$ & $\ldots$ & $\ldots$ & $\ldots$ & $\ldots$ & $\ldots$ & $\ldots$ \\
\hline $\begin{array}{l}\text { Control } \\
(n=4)\end{array}$ & $\begin{array}{l}1713 \\
(100)\end{array}$ & $\begin{array}{l}2193 \\
\text { (128) }\end{array}$ & $\begin{array}{l}1908 \\
(111)\end{array}$ & $\begin{array}{l}2177 \\
(127)\end{array}$ & $\begin{array}{l}2001 \\
(117)\end{array}$ & $\begin{array}{l}1362 \\
(80)\end{array}$ & $\begin{array}{l}2272 \\
(137)\end{array}$ & $\begin{array}{l}2101 \\
(123)\end{array}$ & $\begin{array}{l}1912 \\
(112)\end{array}$ & $\begin{array}{l}1992 \\
(116)\end{array}$ & $\begin{array}{l}1763 \\
(103)\end{array}$ & $\begin{array}{l}2018 \\
(118)\end{array}$ & $\begin{array}{l}2375 \\
(139)\end{array}$ & $\begin{array}{l}1950 \\
(114)\end{array}$ & $\begin{array}{l}2687 \\
(157)\end{array}$ & $\begin{array}{l}2681 \\
(157)\end{array}$ & $\begin{array}{r}2899 \\
(169)\end{array}$ & $\begin{array}{l}2738 \\
(160)\end{array}$ & $\begin{array}{l}3895 \\
(227)\end{array}$ & $\begin{array}{l}5239 \\
(306)\end{array}$ & $\begin{array}{l}5507 \\
(321)\end{array}$ & $\begin{array}{l}4694 \\
(274)\end{array}$ \\
\hline
\end{tabular}

a) Pretreatment. b) Day after treatment. c) Weeks after treatment. d) Numbers of microfilariae in $200 \mu l$ of blood. e) Not counted. f) Percentages to the numbers of pretreatment. g) Adult-worm eliminated. 


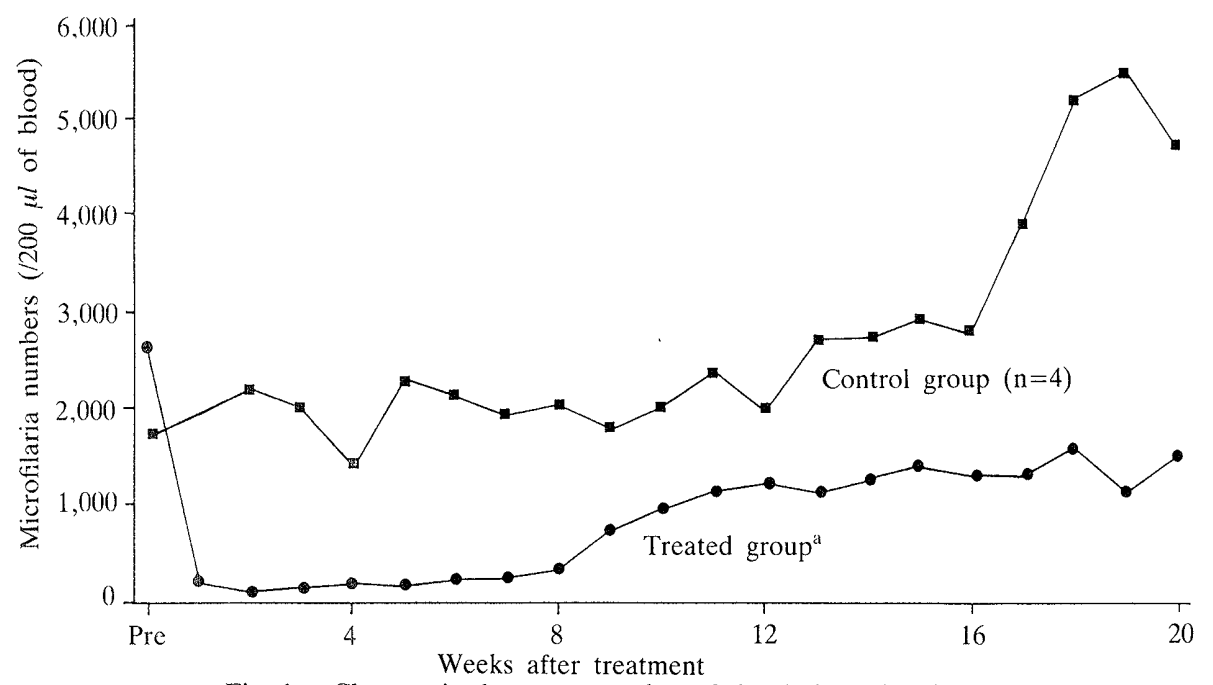

Fig. 1. Changes in the mean number of circulating microfilaria in the peripheral blood of dogs treated with a single dose $(1 \mathrm{mg} / \mathrm{kg}$ ) of milbemycin D. a) Pretreatment to 4 weeks $(n=17), 5$ to 8 weeks $(n=14), 9$ to 12 weeks $(n=10), 13$ to 16 weeks $(n=7), 17$ to 20 weeks $(n=4)$.

Table 2. The numbers of circulating microfilariae followed by milbemycin D administration at monthly intervals in dogs

\begin{tabular}{|c|c|c|c|c|c|c|c|c|c|c|c|}
\hline \multirow{2}{*}{$\begin{array}{l}\text { Dog } \\
\text { Nos }\end{array}$} & \multirow{2}{*}{$\begin{array}{c}\text { Number of } \\
\text { doses }\end{array}$} & \multicolumn{10}{|c|}{ Months after the first milbemycin D administration } \\
\hline & & $0^{\mathrm{b})} \downarrow^{\mathrm{c})}$ & $1 \downarrow$ & $2 \downarrow$ & $3 \downarrow$ & $4 \downarrow$ & $5 \downarrow$ & 6 & 10 & 12 & 20 \\
\hline 1 & 6 & $29630^{\mathrm{d})}$ & 70 & 50 & 76 & 0 & 0 & 0 & $\ldots)^{e)}$ & $\ldots$ & $\cdots$ \\
\hline 2 & 6 & 3570 & 20 & 10 & 44 & 4 & 0 & 0 & $\ldots$ & 0 & 0 \\
\hline 3 & 6 & 7570 & 110 & 30 & 6 & 0 & 0 & 0 & $\ldots$ & $\ldots$ & $\ldots$ \\
\hline 4 & 6 & 350 & 0 & 0 & 0 & 0 & 0 & 0 & $\ldots$ & 0 & $\cdots$ \\
\hline 5 & 6 & 3180 & 34 & 0 & 0 & 0 & 0 & 0 & $\ldots$ & 0 & $\ldots$ \\
\hline 6 & 6 & 755 & 0 & 0 & 0 & 0 & 0 & 0 & $\ldots$ & 0 & $\ldots$ \\
\hline 7 & 6 & 2065 & 5 & 0 & 0 & 0 & 0 & 0 & $\ldots$ & 0 & $\ldots$ \\
\hline 8 & 6 & 1565 & 8 & 8 & 15 & 28 & 4 & 0 & $\ldots$ & 250 & $\ldots$ \\
\hline 9 & 4 & 1880 & 5 & 0 & 0 & 0 & $\ldots$ & $\cdots$ & 0 & $\ldots$ & $\ldots$ \\
\hline 10 & 4 & 910 & 0 & 0 & 0 & 0 & $\ldots$ & $\ldots$ & 0 & $\ldots$ & $\ldots$ \\
\hline 11 & 4 & 100 & 0 & 0 & 0 & 0 & $\ldots$ & $\ldots$ & 0 & $\ldots$ & $\ldots$ \\
\hline 12 & 4 & 150 & 0 & 0 & 0 & 0 & $\ldots$ & $\cdots$ & 0 & $\ldots$ & $\ldots$ \\
\hline
\end{tabular}

a) Six doses of milbemycin D $(1 \mathrm{mg} / \mathrm{kg})$ at monthly intervals (from June to November) given orally to 8 dogs (Nos 1 to 8 ) and 4 doses (from August to November) to 4 dogs (Nos 9 to 12). b) Pretreatment. c) Administration of milbemycin D. d) Number of microfilariae in $200 / \mu \mathrm{l}$ of blood. e) Not counted.

single drug treatment in 5 dogs (Nos. 4, 6, 10, 11 and 12) that had a relatively small number of microfilariae before treatment. Microfilariae also disappeared after 2 treatments in 3 dogs (Nos. 5, 7 and 9), and after 4 to 6 treatments in 4 dogs (Nos. 1, 2, 3 and 8). In nine of ten dogs examined 12 or 10 months after the 1st treatment (in June of the next year), no microfilariae were detected in the peripheral blood. No microfilariae were observed 20 months after the 1st treatment in a dog (No. 2) examined.

2. Effect on reproduction of microfilariae

Light microscopic findings: Motions of microfilariae did not differ among the 1-day, 1-week, 4-week and the control groups. Ovaries, seminal receptacles, early-stage embryos (zygote to 8-cleavage-cell), morulae, tadpoles, coiling-microfilariae in egg-sacs, and mature microfilariae were seen continuously from the post-end to the prior-end of the uteri in the worms of control group. Embryos of each stage were located roughly in fixed body parts. Varying numbers of degenerative embryos, which showed karyorrhexis or karyolysis with acidophilic cytoplasm, were noticed in almost all the worms of the control group.

There were no morphological differences in germinal cells, embryos and microfilariae among the 1-day, 1-week, 4-week, and control groups. The abnormal embryos described, which were not observed in the control group, were recognized in the 8 - to 20 -week group. In mildly abnormal embryos, a small number of early-stage embryos with large and faint nuclei were observed within normal morulae and tadpoles (Fig. 2). In moderately abnormal embryos, cleavage cells in morulae, which aggregated densely within the egg-sacs or scattered out of the egg-sacs, were dark and shrunken, so that the nucleus and cytoplasm could not be distinguished (Fig. 3). These abnormal morulae were seen in the more anterior parts of the worm body as compared with the control group worms, and the number of tadpoles and microfilariae decreased. In severely abnormal embryos, tadpoles and microfilariae almost disappeared, and a small number of degenerated morulae and debris of embryos were seen as far as the anterior part of the uteri (Fig. 4).

The incidence of embryo abnormalities, which were not seen in embryos of the control group, is summarized in Table 3. In the 8-week group, the mildly abnormal embryos were observed in 4 of 10 worms collected from 2 of 4 dogs. In the 12-week group, mildly or moderately abnormal embryos were seen in 10 worms from 2 of 3 dogs. In the 16- and 20-week groups, mildly to severely abnormal embryos were seen in all the worms. Thus the 


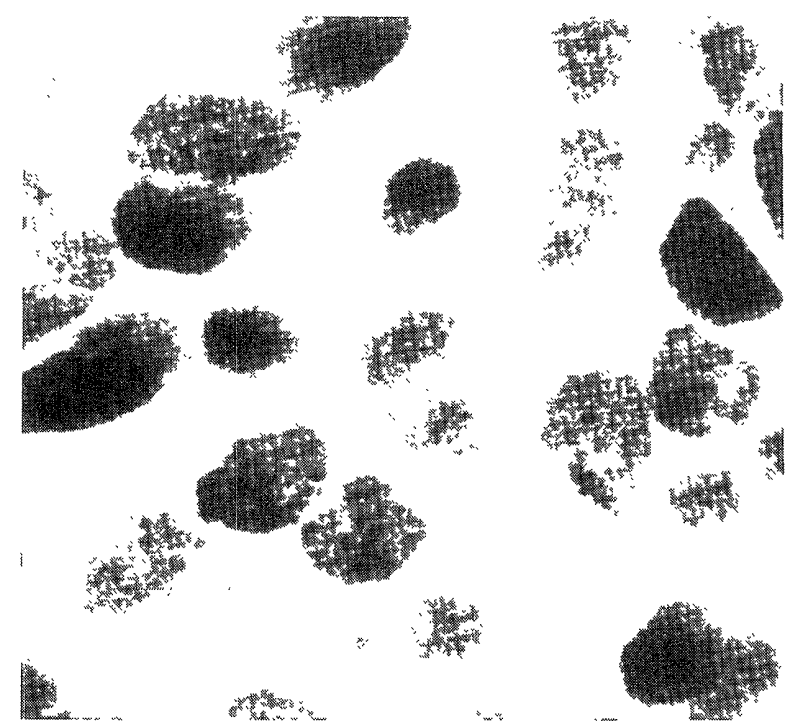

Fig. 2. Abnormal embryos in a worm of the 8 -week group. Zygotes or two-cell embryos with large and faint nucleus were observed within normal morulae and tadpole stage embryos. $\times 600$.

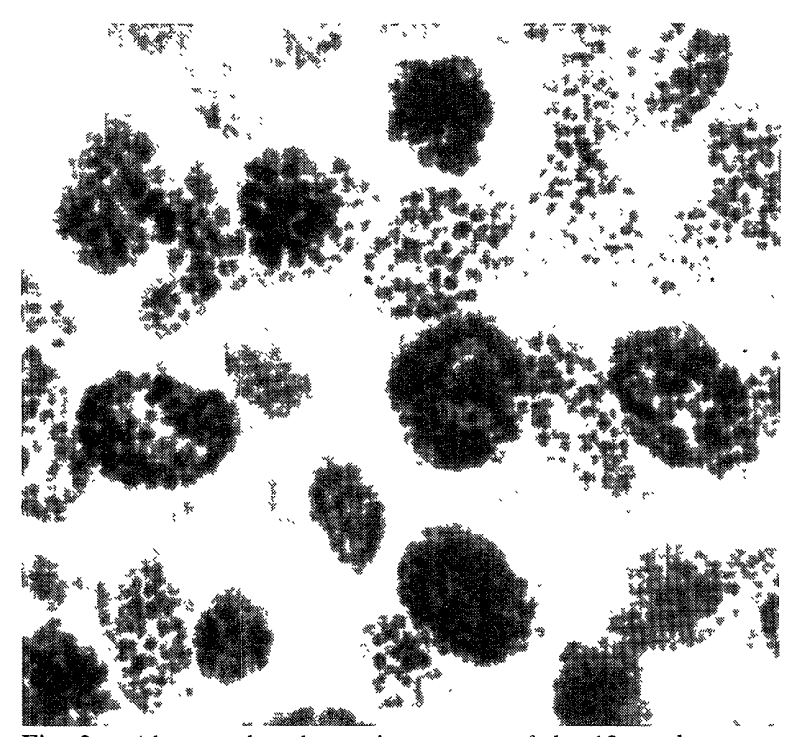

Fig. 3. Abnormal embryos in a worm of the 12-week group. Cleavage cells of morula stage embryos were dark and shrunken, and the nucleus and cytoplasm could not be distinguished. $\times 600$.

abnormalities in the embryos became worse with time. Severely abnormal embryos were also observed in 4 worms collected from a dog 20 months after the 1st treatment in the multiple-dose experiment. However, no abnormalities were noticed in the germinal cells of ovaries and zygotes in the seminal receptacle of any cases.

Electron-microscopic findings: In primary and secondary oocytes, nucleoli were very dense, and the structure of nucleolonema was more obscure in the worms of 1-, 4and 8-week groups than in those of the control group (Fig. $5-a, 5-b)$. However, no changes in cytoplasmic organs such as mitochondria, Golgi apparatus and ribosomes were

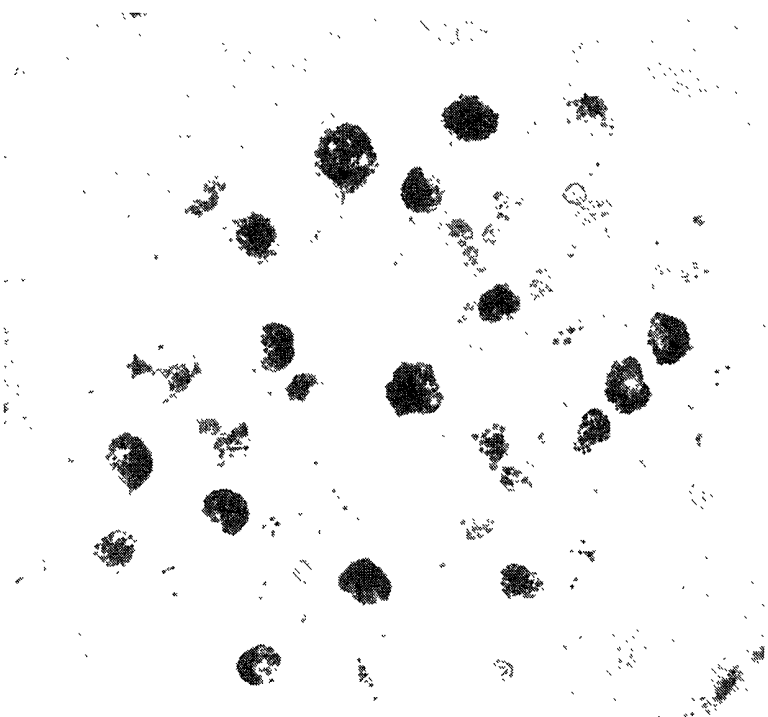

Fig. 4. Anterior part of the uterus in a worm of the 20 -week group. Microfilariae disappeared, and a small number of degenerated embryos were scattered throughout the uterine contents. $\times 200$.

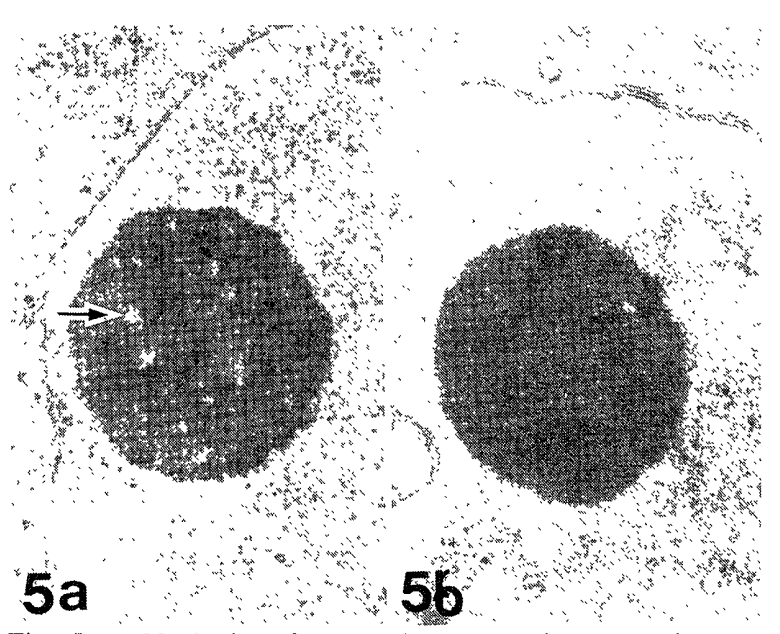

Fig. 5-a. Nucleolus of a secondary oocyte in a control worm. Protein components (arrow) were seen in the granules. $\times 13,000$.

Fig. 5-b. Nucleolus of a secondary oocyte in a worm of the 1-week group. Protein components were not observed and granular components were obscure due to high density. $\times 13,000$.

recognized. In zygotes of the control group, a large number of mitochondria, free-form polysomes and endoplasmic reticula with tubular or rod-shapes were seen in the cytoplasm (Fig. 6-a). In abnormal zygotes in the worms of 8 - and 12-week groups, the endoplasmic reticula were slender, and a few free-form polysomes were seen in the cytoplasm (Fig. 6-b). In the early-stage embryos in the worms of control group, numerous polysomes, smoothendoplasmic reticula, Golgi apparatus and mitochondria were observed in the cytoplasm of each cleavage cell (Fig. 7-a). In the 12-week group, cleavage cells were unequal in size, and some cleavage cells had 2 nuclei, a few free-form 
Table 3. Incidence of heartworms with histologic findings of abnormal embryos after the treatment with a single dose $(1 \mathrm{mg} / \mathrm{kg})$ of milbemycin $\mathrm{D}$ in dogs

\begin{tabular}{rccccccc}
\hline Group & \multicolumn{2}{c}{ Number of worms with abnormal embryos ${ }^{\text {a) }}$} & \multicolumn{2}{c}{$\begin{array}{c}\text { Number of dogs having worms } \\
\text { with abnormal embryos }\end{array}$} \\
\cline { 3 - 5 } & - & + & ++ & +++ & total & & \\
\hline 8 week & $18^{\text {b) }}(82)^{\text {c) }}$ & $4(18)$ & 0 & 0 & $22(100)$ & $2 / 4^{\text {d) }}(50)$ \\
12 week & $6(38)$ & $2(12)$ & $4(25)$ & $4(25)$ & $16(100)$ & $2 / 3$ & $(67)$ \\
16 week & 0 & $1(7)$ & $4(29)$ & $9(64)$ & $14(100)$ & $3 / 3(100)$ \\
20 week & 0 & 0 & $2(15)$ & $11(85)$ & $13(100)$ & $4 / 4(100)$ \\
\hline
\end{tabular}

a) Abnormalities in embryos: - ...No abnormality, +...Mild abnormality (early stage embryos with large and faint nucleus were noticed within morulae or tadpoles), ++...Moderate abnormality (cleavage cells in the morula were dark and shrunken, and nuclei and the cytoplasm were not distinguishable),$+++\ldots$ Severe abnormality (tadpoles and microfilariae in the uteri were almost completely absent). b) Number of worms. c) Percentage of total worms examined. d) Number of dogs having abnormal worms/number of dogs examined.

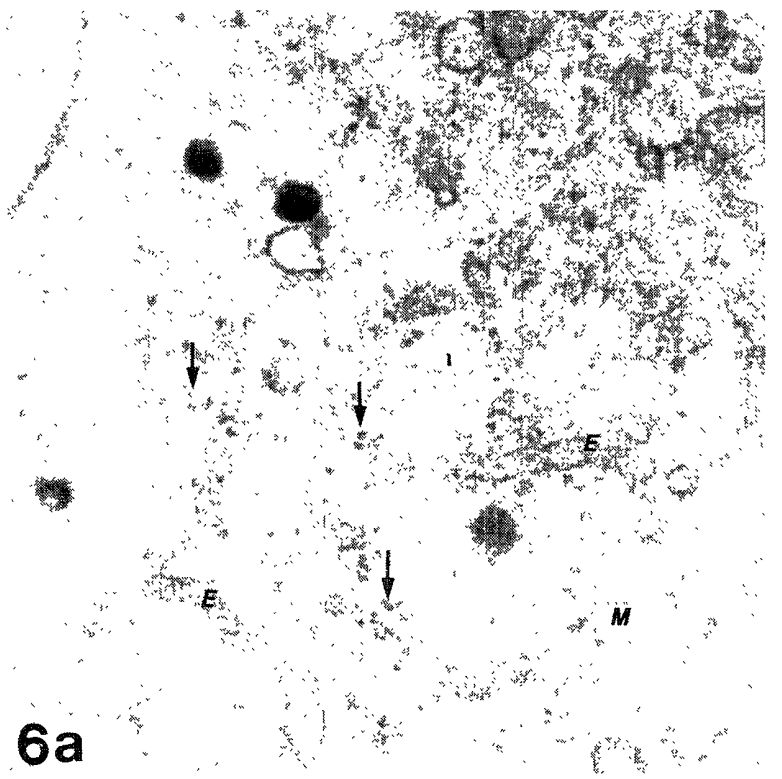

Fig. 6-a. Zygote of a worm of the control group. A large number of mitochondria (M), free-form polysomes (arrows) and tubular or rod-shaped endoplasmic reticulum (E) were seen in the cytoplasm. $\times 12,000$.

polysomes and tubular structures (Fig. 7-b). In abnormal morulae and tadpoles, the cleavage cells were shrunken, and spaces between the cells were expanded with vacuoles. The structure of the cytoplasm and the nucleolus could not be distinguished because of high cell density.

DISCUSSION

The findings in the adult-worm eliminated group confirmed that a dose of $1 \mathrm{mg} / \mathrm{kg}$ of milbemycin $\mathrm{D}$ had a strong microfilaricidal action. In the single-dose experiment, the number of circulating microfilariae decreased 1 week after the treatment, not increased till 8 weeks, and increased slightly thereafter. These findings suggest that circulating and intrauterine microfilariae may be simultaneously killed by the drug, and the reproduction of microfilariae may cease for some weeks after the treatment. However, milbemycin D did not destroy directly

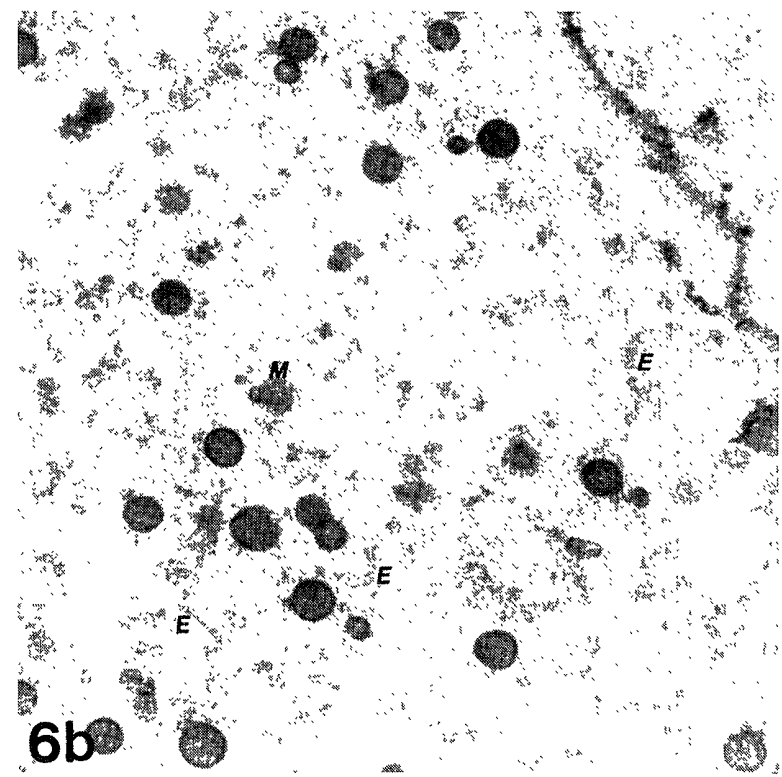

Fig. 6-b. An abnormal zygote in a worm of the 8-week group.

A few free-form polysomes and slender reticulum were seen.

$\times 12,000$.

intrauterine microfilariae, embryos and germinal cells of heartworms. Microfilariae might therefore have been reproducing normally for some weeks after the drug administration. Then 12 weeks after the treatment the number of intrauterine microfilariae began to decrease gradually with time. The discrepancy between the number of circulating microfilaria and morphological findings on the intrauterine microfilariae could not be well explained. It has been assumed that circulating microfilariae may appear after a considerable number of them accumulate within the visceral-vascular system in the initially infected dogs [8]. This assumption apply to the present study.

The change in the number of circulating microfilaria after the treatment with avermectin or ivermectin showed the same pattern as that with milbemycin $\mathrm{D}[1,3,5,9]$. The number of coiling microfilariae and tadpoles in the uteri of heartworms decreased 80 days after ivermectin treatment [7]. Only degenerated morulae but no intrauter- 


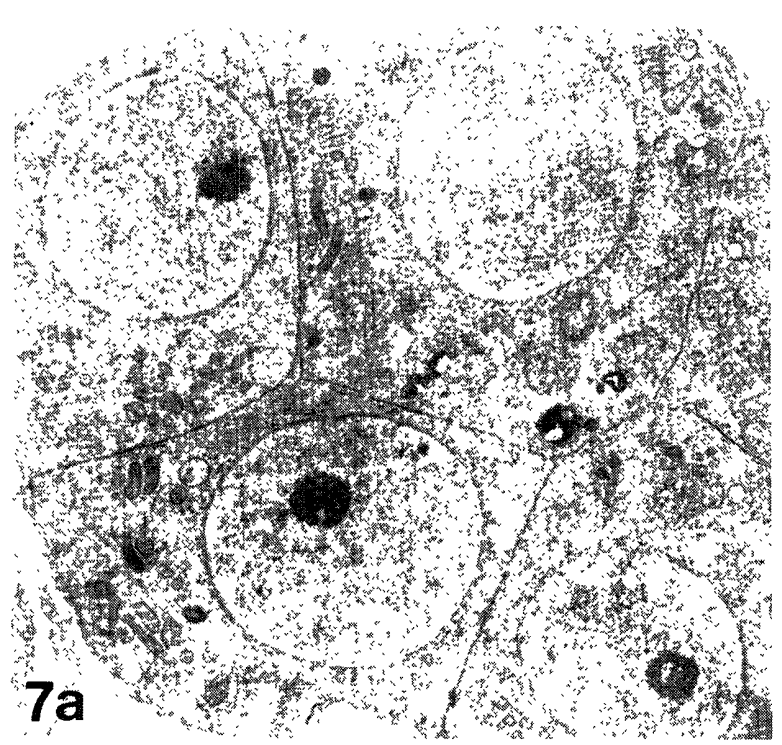

Fig. 7-a. An early-stage embryo in a worm of the control group. Each cleavage cell was almost the same size, and contained numerous free-form polysomes and smoothendoplasmic reiculum in cytoplasm. $\times 9,000$.

ine microfilariae were noticed 20 weeks after ivermectin treatment [1]. Thus ivermectin may have the same effect on the reproduction of heartworms as milbemycin D.

In the multiple-dose experiment, circulating microfilariae disappeared completely after several treatments. No microfilaremia was confirmed at the beginning of the next mosquito season in almost all the cases and in a case examined 20 months after the first treatment. Occult heartworm infection might be induced when milbemycin $\mathrm{D}$ is used for prophylaxis in microfilaremic dogs [12], and it will be difficult to make a diagnosis by microfilaria detection.

In a dog in the 12-week group of a single-dose experiment, the number of circulating microfilariae was increased more rapidly than the other dogs. In a dog of the multiple-dose experiment, circulating microfilariae appeared at the next mosquito season. It was suspected that the absorption of the drug from the digestive organ in these dogs might be relatively less than the other dogs in the single-dose and multiple-dose experiments.

Electron microscopically, high density nucleoli and obscure nucleolonema in the primary and secondary oocytes were seen in the worms of 1-, 4- and 8-week groups. A few free-form polysomes and unequal-size cleavage cells were observed in the zygotes or early stage embryos in the 8- to 20-week groups. The free-form polysomes produce proteins to construct the cells themselves. The number of polysomes is increases when protein synthesis is active, especially in the embryo, and is decreases when the synthesis is inactive [16]. Polysomes are formed from messenger-RNA (mRNA) and ribosomes, and mRNA is synthesized in the nucleolus. When the cells are treated with drugs such as actinomycin D, which impair RNA formation, nucleoli is therefore shrunken and ribosomes or polysomes are decrease in

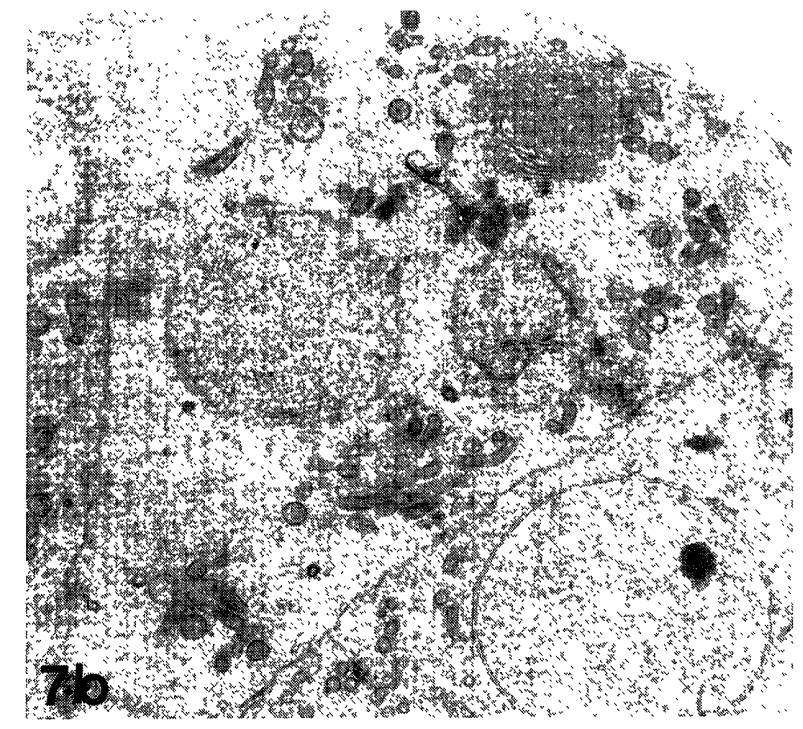

Fig. 7-b. An abnormal early-stage embryo in a worm of the 12-week group. Cleavage cells were unequal in size, and some had 2 nuclei, a few free-form polysomes and tubular structures. $\times 11,000$.

number $[6,16]$. The high density of nucleoli, the obscurity of nucleolonema in oocytes, and reduction of polysomes in the early stage embryos suggested that the ability of the embryos to produce proteins might be declined $[6,16]$. The lack of protein at the morula stage, when proteins were needed, led to possible embryo degeneration. Inhibition of embryonic development was also recognized 20 months after treatment. These findings suggest that milbemycin D may have some effects on chromosomes or genes of stem-cells in germinal-cells, inducing insufficient protein synthesis.

The present findings made it clear that milbemycin D does not kill intrauterine microfilariae, but inhibits the development of heartworm embryos. Moreover, its prophylactic use in microfilaremic dogs will induce occultinfection cases.

REFERENCES

1. Anantaphruti, M., Kino, H., Terada, M., Ishii A, I., and Sano, M. 1982. Studies on chemotherapy of parasitic helminths (XIII). Efficacy of ivermectin on the circulating microfilaria and embryonic development in the female worm of Dirofilaria immitis. Jpn. J. Parasitol. 31: 517-529.

2. Ashburn, L. L., Perrin, T. L., Brady F. J., and Lawton, A. H. 1945. Histologic changes in ovary and uterus of live Dirofilaria immitis recovered from dogs treated with trivalent antimony compounds. Arch. Pathol. 40: 334-339.

3. Blair, L. S. and Campbell, W. C. 1979. Efficacy of avermectin $\mathrm{B}_{1}$ a against microfilariae of Dirofilaria immitis. Am. J. Vet. Res. 40: 1031-1032.

4. Boisveneu, R. J., Hendrix, J. C., Rathmacher, R. P., and Todd, G. C. 1975. Effectiveness of low doses of dithiazanine iodide on microfilariae of Dirofilaria immitis in dogs with established infections. (pp. 93-97). In: Proceedings of the Heartworm Symposium '74 (Otto, G. F. ed.), Veterinary Medicine Publishing Co., Edwardsville. 
5. Jackson, R. F. and Seymour, W. G. 1981. Efficacy of avermectins against microfilariae of Dirofilaria immitis. pp. 131-136. In: Proceedings of the Heartworm Symposium ' 83 (Otto, G. F. ed.), Veterinary Medicine Publishing Co., Edwardsville.

6. Koshihara, H. 1974. Morphology and chemical composition of nucleous. pp. 1-23. In: Saibougaku Taikei (Outline of Cell) 4 (Ogawa, K., Oda, T., Kurozumi, K., and Sugino, Y. eds.), Asakura Shoten, Tokyo (in Japanese).

7. Lok, J. B., Harpaz, T., and Knight, D. H. 1988. Abnormal patterns of embryogenesis in Dirofilaria immitis treated with ivermectin. J. Helminthol. 62: 175-180.

8. Ohoishi, I. 1986. Inushijouchu (Dirofilalia immitis). Buneidou Co., Ltd., Tokyo (in Japanese).

9. Plue, R. E., Seward, R. L., Acre, K. E., Cave, J. S., Schlotthauer, J. C., and Stromberg, B. E. 1985. Clearance of Dirofilaria immitis microfilariae in dogs using $200 \mathrm{mg} / \mathrm{kg}$ ivermectin subcutaneously. pp. 153-160. In: Proceedings of the Heartworm Symposium '83 (Otto, G. F. ed.), Veterinary Medicine Publishing Co., Edwardsville.

10. Sakamoto, T., Seki, I., Kikuchi, K., Nakahara, H. Ogasawara, H., Hattori, M., and Hakura, R. 1984. Anthelmintic effect of milbemycin D on parasites in dogs. J. Fac. Agric. Iwate Univ. 17: 69-81.

11. Sasaki, Y., Kitagawa, H., Ishihara, K., and Mori, M. 1988. Clinical application of milbemycin D as a prophylactic agent against Dirofilaria immitis infection in dogs: Pathological findings following administration. Jpn. J. Vet. Sci. 50: 977-984.

12. Sasaki, Y., Kitagawa, H., Ishihara, K., and Shibata, M. 1989. Prevention of adverse reactions following milbemycin $D$ administration to microfilaremic dogs infected with Dirofilaria immits. Jpn. J. Vet. Sci. 51: 711-715.

13. Sasaki, Y., Kitagawa, H., Okachi, H., Kajita, Y., and Ishihara, K. 1986. Clinical application of milbemycin D as a prophylactic agent against Dirofilaria immitis infection in dogs: Reactions in uninfected and infected dogs. Jpn. $J$. Vet. Sci. 48: 579-586.

14. Tagawa, M., Takiyama, A., Ejima, H., and Kurokawa, K. 1985. Prophylactic efficacy of milbemycin D against Dirofilaria immitis infection in Dogs. Jpn. J. Vet. Sci. 47: 787-790.

15. Taylor, A. E. R. and Terry, R. J. 1960. The effect of antifilarial drugs on the embryonic development of litomosoides carinii, of the cotton-rat. Trans. R. Soc. Trop. Med. Hyg. 54: 33-36.

16. Tashiro, H. 1974. Ribosome and polysome. pp. 30-78. In: Saibougaku Taikei (Outline of Cell) 2 (Ogawa, K., Oda, T., Kurozumi, K., and Sugino, Y. eds.), Asakura Shoten, Tokyo (in Japanese).

17. Tamashiro, W. K. and Palumbo, N. E. 1985. Diethylcarbamazine: In vitro inhibitory effect on microfilarial production by Dirofilaria immitis. J. Parasitol. 71: 381-383. 